\title{
The use of heap bioleaching as a pre-treatment for platinum group metal leaching
}

\author{
James M. Mwase ${ }^{1}$ and Jochen Petersen ${ }^{2, *}$
}

1. GeMMe, Mineral Processing and Recycling, University of Liege, Liege, Belgium

2. Department of Chemical Engineering, University of Cape Town, Rondebosch, South Africa

* Corresponding author: email: jochen.petersen@uct.ac.za

Keywords: Bioleaching, heap leaching, Metallosphaera hakonensis, base metals, platinum group metals

\begin{abstract}
Two samples, a Platreef flotation concentrate and coarse ore $(<6 \mathrm{~mm})$, were column bioleached at $65^{\circ} \mathrm{C}$ using a culture dominated by Metallosphaera hakonensis. Based on solution assays, extractions in excess of $90 \% \mathrm{Cu}$ and $\mathrm{Ni}$ were achieved from the flotation concentrate, while from the coarse ore $96 \% \mathrm{Cu}$ and $67 \% \mathrm{Ni}$ extractions were achieved. The difference in extraction levels and leaching patterns despite identical conditions used for both samples is discussed, as is the performance of the samples during a follow-up leach step using cyanide to extract the PGMs in a separate column leach experiment. While the recovery of $\mathrm{Pd}$ and $\mathrm{Au}$ was excellent during these steps, recovery of Pt was limited to $35 \%$ after 45 days for the concentrate and $56 \%$ after 60 days for the whole ore material, primarily due to the presence of a refractory Pt mineral. Recovery from a concentrate without pre-treatment was substantially lower.
\end{abstract}

\section{Introduction}

The majority of platinum group metals (PGMs) are recovered from $\mathrm{Ni}-\mathrm{Cu}$ smelter mattes produced from PGM bearing ores after concentration, and a small quantity is recovered from spent catalysts and copper anode slimes [1]. A critical step in the process is a pressure oxidation leach (in either sulfuric acid or ammonia solution) to leach base metals from the matte, prior to a more aggressive chloride leach to leach the residual PGMs. This approach is not feasible for leaching lower grade and secondary materials. The aim of this study is to investigate the use of heap bioleaching, in a simulated environment, as a pre-treatment to PGM leaching from low grade materials to solubilise base metals and liberate PGM bearing minerals for recovery in a secondary leach step.

\section{Experimental}

Materials. The test samples used originated from Platreef ore obtained from the Bushveld Igneous Complex in South Africa. Sample A was low-grade flotation concentrate (83\% passing $38 \mu \mathrm{m})$ and Sample B was crushed coarse ore screened to a size fraction of $-6 \mathrm{~mm}+1 \mathrm{~mm}$. Analysis via a Mineral Liberation Analyser (MLA) confirmed that $\mathrm{Cu}$ and $\mathrm{Ni}$ in the concentrate were primarily as chalcopyrite and pentlandite, respectively. Fe was present as pyrite and pyrrhotite with the bulk of the sample being composed of silicate and chromite minerals (Table 1). It was suspected that the coarse ore also originating from the Platreef ore body had a similar mineralogy.

Method. Cylindrical columns with heating coils wound around them (Figure 1) were used to simulate thermophilic heap bioleaching. $500 \mathrm{~g}$ of the concentrate was made into slurry and coated onto $3.5 \mathrm{~kg}$ of granite pebbles, and a sample of $4 \mathrm{~kg}$ of the coarse ore was prepared. The two charges were packed into separate columns in between layers of glass marbles that acted as distributors of feed from above and below the column. The columns were fed from the top with a solution made of $10 \mathrm{~g} / \mathrm{L} \mathrm{H}_{2} \mathrm{SO}_{4}$ and 
$1 \mathrm{~g} / \mathrm{L} \mathrm{Fe}^{2+}$ (ferrous sulphate) at a rate of $5 \mathrm{Lhr} / \mathrm{m}^{2}$. The columns were aerated at a rate of $1 \mathrm{~m}^{3} \mathrm{hr} / \mathrm{m}^{2}$ and operated at $65^{\circ} \mathrm{C}$.

Bacterial Culture. The culture used consisted mostly (99\%) of Metallosphaera hakonensis, identified and quantified through quantitative real time polymerase chain reaction (qRT PCR) by the Centre for Bioprocess Engineering Research (CeBER) at the University of Cape Town. Within the centre, the culture had previously been used successfully in high temperature $\mathrm{Fe}$ oxidation experiments [2].

Analyses. Solution samples were taken during the entire duration of the experiments to analyse for base, gangue and precious metals via atomic absorption spectroscopy (AAS). The redox and $\mathrm{pH}$ were also monitored using standard laboratory $\mathrm{pH}$ and redox probes. On completion of the experiments sub-samples of the residual materials were analysed for $\mathrm{S}$ using a sulphur LECO combustion test.

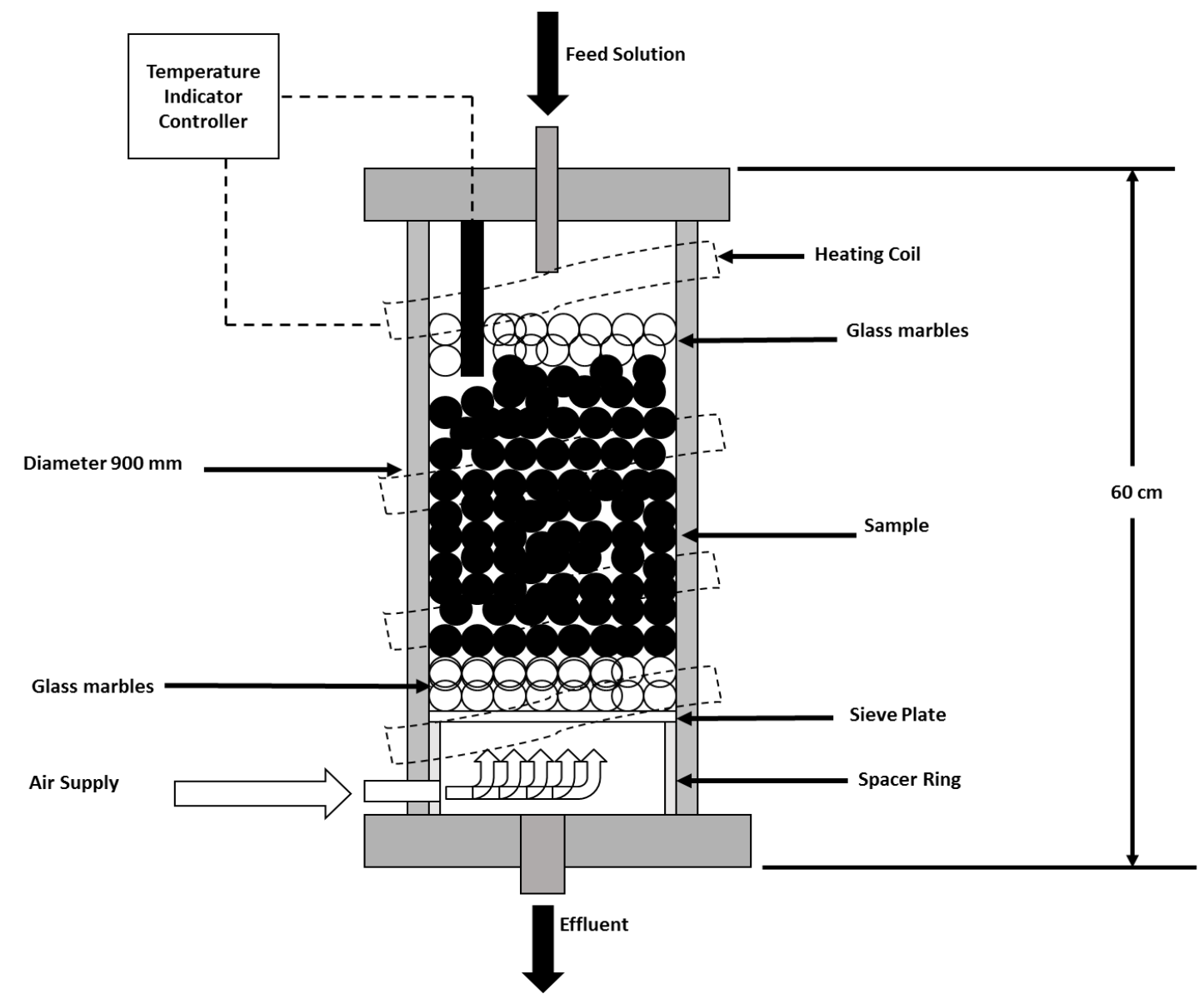

Figure 1: Schematic diagram of cylindrical columns used for experiments

Table 1: Grades of elements and minerals of importance to study

\begin{tabular}{ccccccccc}
\hline & $\mathrm{Cu}$ & $\mathrm{Ni}$ & $\mathrm{Co}$ & $\mathrm{CuFeS}_{2}$ & $(\mathrm{Fe}, \mathrm{Ni})_{9} \mathrm{~S}_{8}$ & $\mathrm{FeS}_{2}$ & $\mathrm{Fe}_{(1-\mathrm{x})} \mathrm{S}_{\mathrm{x}}$ & $\mathrm{PGMs} \mathrm{6E}^{\wedge}$ \\
& {$[\%]$} & {$[\%]$} & {$[\%]$} & {$[\%]$} & {$[\%]$} & {$[\%]$} & {$[\%]$} & {$[\mathrm{g} / \mathrm{t}]$} \\
\hline $\mathbf{A}$ & 2.3 & 3.4 & 0.1 & 4.9 & 7.7 & 1.9 & 5.3 & 55.6 \\
$\mathbf{B}$ & 0.1 & 0.4 & $129^{\#}$ & 0.8 & 1.7 & 0.1 & 1.8 & 4.6 \\
\hline
\end{tabular}

${ }^{\wedge}$ The combined grade of $\mathrm{Pt}, \mathrm{Pd}, \mathrm{Rh}, \mathrm{Ru}, \mathrm{Ir}$ and $\mathrm{Au}$

${ }^{\#}$ Grade for Co in coarse ore was in $\mathrm{g} / \mathrm{t}$ 


\section{Results and Discussion}

Both the experiments achieved high extractions of the critical base metals $\mathrm{Cu}$ and $\mathrm{Ni}$, mostly attributed to the sulphidic nature of the $\mathrm{Cu}$ and $\mathrm{Ni}$ minerals. A comparison between the two experiments shows that more $\mathrm{Ni}$ was leached from the concentrate than from the coarse ore. In the concentrate (Figure 2) the extents to which $\mathrm{Ni}$ and $\mathrm{Cu}$ are leached are similar. They both seem to initially leach at a similar rate for the first 40 days, although $\mathrm{Ni}$ achieves this rate earlier than $\mathrm{Cu}$ and hence leaches to a greater extent. Both begin to reduce in rate of extraction at the same time, with $\mathrm{Cu}$ dropping slightly quicker than $\mathrm{Ni}$ until their final extraction levels. In the case of the coarse ore (Figure 3) again they leach at similar rates with $\mathrm{Ni}$ attaining the rate slightly earlier than $\mathrm{Cu}$. After 180 days the $\mathrm{Ni}$ levels off while $\mathrm{Cu}$ continues to leach. It is suspected that unlike the concentrate perhaps not all the Ni in the coarse ore was in sulphide mineral form.

Table 2: Percentage extractions of $\mathrm{Cu}, \mathrm{Ni}, \mathrm{Co}$ and $\mathrm{Fe}$, along with percentage quantity of $\mathrm{S}$ oxidised

\begin{tabular}{lllllll}
\hline & $\begin{array}{l}\text { Duration } \\
{[\text { Days }]}\end{array}$ & $\begin{array}{ll}\mathrm{Cu} \\
{[\%]}\end{array}$ & $\begin{array}{l}\mathrm{Ni} \\
{[\%]}\end{array}$ & $\begin{array}{l}\mathrm{Co} \\
{[\%]}\end{array}$ & $\begin{array}{l}\mathrm{Fe} \\
{[\%]}\end{array}$ & $\begin{array}{l}\mathrm{S} \\
{[\%]}\end{array}$ \\
\hline $\mathrm{A}$ & 88 & 91 & 99 & 88 & 38 & 56 \\
$\mathrm{~B}$ & 304 & 96 & 67 & 45 & 48 & 75 \\
\hline
\end{tabular}

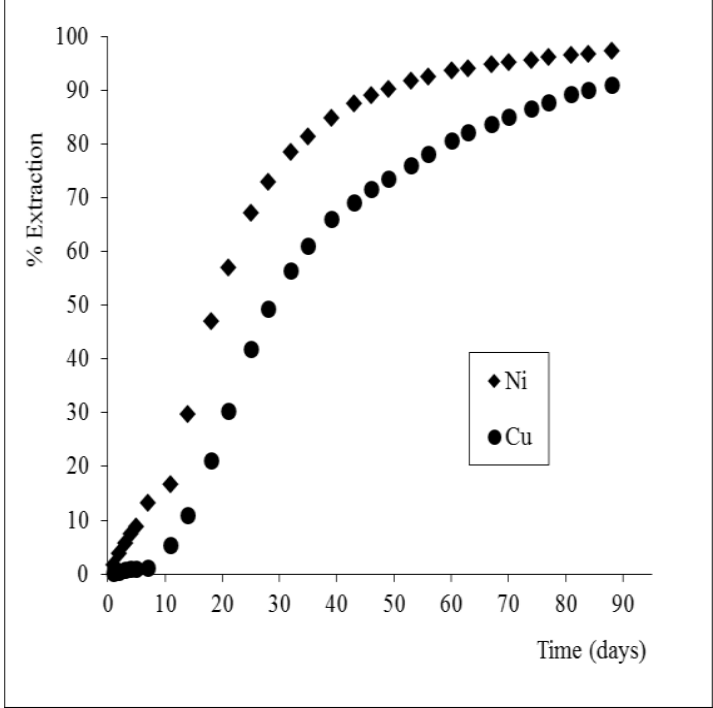

Figure 2: $\mathrm{Ni}$ and $\mathrm{Cu}$ leach curves for bioleach experiment with flotation concentrate. Fed rate of $5 \mathrm{Lhr} / \mathrm{m}^{2}, 65^{\circ} \mathrm{C}, 1 \mathrm{~g} / \mathrm{L} \mathrm{Fe}^{2+}$, aeration of $1 \mathrm{~m}^{3} \mathrm{hr} / \mathrm{m}^{2}$

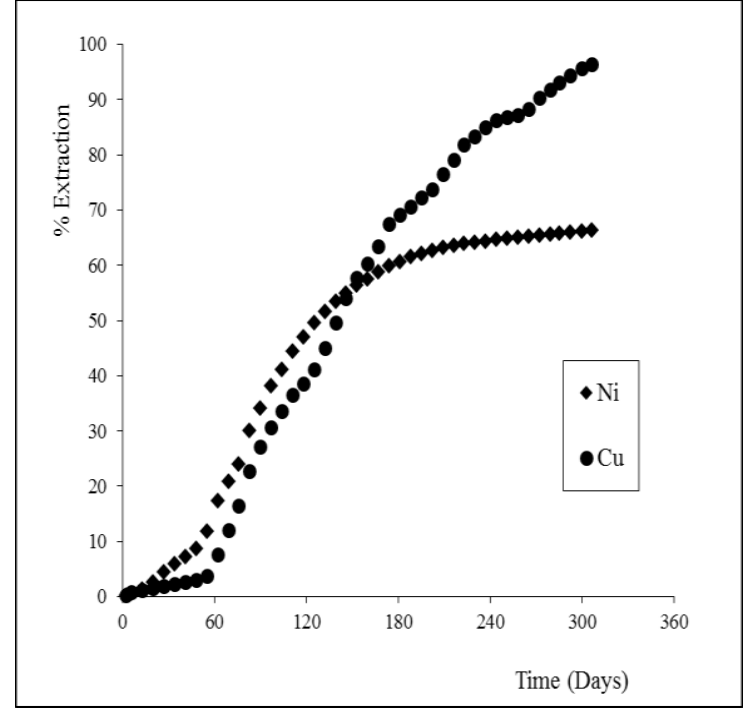

Figure 3: $\mathrm{Ni}$ and $\mathrm{Cu}$ leach curves for bioleach experiment with coarse ore. Fed rate of $5 \mathrm{Lhr} / \mathrm{m}^{2}$, $65^{\circ} \mathrm{C}, 1 \mathrm{~g} / \mathrm{L} \mathrm{Fe}^{2+}$, aeration of $1 \mathrm{~m}^{3} \mathrm{hr} / \mathrm{m}^{2}$

In the concentrate experiment a galvanic effect [3] may have been responsible for the faster and higher Ni extraction. The pentlandite in contact with chalcopyrite may have experienced preferential leaching having a lower rest potential and thus acting as an anode with chalcopyrite acting as a cathode. In the coarse ore experiment this effect was absent since there was little or no contact with the mineral grains, as confirmed by MLA analysis. In the concentrate sample the contact between pentlandite and chalcopyrite was facilitated by the fine grinding of the samples, resulting in high surface exposure and hence contact between mineral grains.

The residual materials from the bioleaching experiments were subsequently subjected to secondary cyanide leaching experiments at $50^{\circ} \mathrm{C}$ using identical columns [4, 5]. The recoveries of Pd and Au were excellent, often exceeding 90\%, while recovery of Pt was limited to 35\% 
after 45 days for the concentrate and $56 \%$ after 60 days for the coarse ore material. Further cyanide leaching test work was conducted on the low-grade concentrate using batch stirred tank reactors [4]. The results showed that the Pt recovery from un-treated samples was substantially lower than samples pre-treated with bioleaching or direct acid leaching. The allaround low Pt extractions were ultimately attributed to a cyanide-refractory Pt mineral phase in both the concentrate and the coarse ore.

High pressure liquid chromatography (HPLC) analysis of the cyanide leachate showed high levels of thiocyanate in both experiments. The absence of elemental sulphur in the bioleached materials lead to the conclusion that incomplete sulphur oxidation (Table 2) resulted in the formation of intermediate sulphur species that were highly reactive with the cyanide forming thiocyanate. The use of a mixed culture consisting of both Fe oxidising microorganisms and specialised sulphur oxidising microorganisms would most likely mitigate this problem [6].

\section{Conclusion}

Heap bioleaching has shown to be a promising route to further explore at pilot scale for pretreating low-grade PGM ores for subsequent secondary leaching of precious metals using lixiviants such as cyanide. Extraction of base metals such as $\mathrm{Cu}, \mathrm{Ni}$ and $\mathrm{Co}$ not only removes elements that would otherwise increase cyanide consumption, but also produces commercial value. The use of a mixed culture of both $\mathrm{Fe}$ and $\mathrm{S}$ oxidising microorganisms is recommended to facilitate complete sulphur oxidation especially in cases where cyanide leaching succeeds bioleaching as the means of PGM extraction.

\section{References}

[1] Crudwell F.K., Moats, M.S., Ramachandran, V., Robinson, T.G., Davenport, W.G. 2011. "Extractive metallurgy of nickel, cobalt and platinum-group metals", Elsevier, Kidlington, Oxford, UK.

[2] Searby, G.E. 2006. "An investigation of the kinetics of thermophilic microbial ferrous iron oxidation in continuous culture", $\mathrm{PhD}$ thesis, Department of Chemical Engineering, University of Cape Town.

[3] Bharathi, K., Lakshmi, M., Ravindra, P. 2008. "Role of galvanic interaction in selective leaching of nickel from copper flotation concentrate", Advances in Natural and Applied Sciences, vol. 2, issue 2, pp 68-72.

[4] Mwase, J.M., Petersen, J., Eksteen, J.J. 2012. “Assessing a two-stage heap leaching process for Platreef flotation concentrate”, Hydrometallurgy, 129-130, pp74-81.

[5] Mwase, J.M., Petersen, J., Eksteen, J.J. 2014. “A novel sequential heap leach process for treating Platreef ore", Hydrometallurgy, 141, pp 97-104.

[6] Aswegen, P.C., Van Niekerk, J., Olivier, W. 2007. "The BIOX'M process for treatment of refractory gold concentrates", In Rawlings, D.E., Johnson, D.B. (Eds.) 2007. "Biomining", Springer-Verlag, Berlin, Heidelberg. 